\title{
Management Strategies for Acute Cholecystitis: Is the Timing of Surgery Important?
}

\section{Akut Kolesistit için Tedavi Stratejileri: Cerrahi Zamanlamasının Bir Önemi Var Mıdır?}

Özgür Ekinci1, (D) Tunç Eren¹, (D) Aman Gapbarov1', (D) Damla Beyazadam¹, (D) Nurgül Bulut², (D) Metin Leblebici', (D) Orhan Alimoğlu

${ }^{1}$ Istanbul Medeniyet University Göztepe City Hospital, Department of General Surgery, Istanbul, Turkey

${ }^{2}$ Istanbul Medeniyet University, Department of Biostatistics and Medical Informatics, Istanbul, Turkey

\begin{abstract}
Objective: The timing of cholecystectomy is still controversial in acute cholecystitis (AC). This study aimed to evaluate the outcomes of early cholecystectomy (EC), delayed cholecystectomy (DC), and non-operative management (NOM) for AC.

Methods: The patients with AC, who were treated in a one-year-period, were divided into EC, DC, and NOM subgroups. Parameters, including demographics, laboratory results, imaging findings, body mass index (BMI), American Society of Anesthesiologists (ASA) score, the timing of surgery, operative time, gallstone size, postoperative complications, and postoperative length of hospital stay were analyzed.

Results: The study group of 125 patients comprised of 71 patients $(56.8 \%)$ in the EC, $29(23.2 \%)$ in the DC, and 25 patients $(20 \%)$ in the NOM group. Patients in the NOM group were relatively older $(p<0.05)$. BMI values and physical examination findings were similar among the subgroups ( $p>0.05)$. The incidence of ASA score of 3 and the mean levels of bilirubin, aspartate aminotransferase, and alanine aminotransferase was higher, whereas the mean hemoglobin value was lower in the NOM group $(p<0.05)$. Gallstones smaller than $1 \mathrm{~cm}$ were more common in the DC group $(p<0.05)$. The mean operative times, conversion rates, and postoperative complications were similar between the EC and DC groups $(p>0.05)$. The length of hospital stay was shorter in the DC group $(p<0.05)$.
\end{abstract}

Conclusion: The surgical treatment of hospitalized patients with $\mathrm{AC}$ can be performed anytime within the first week of their admissions unless the clinical and laboratory findings render the patient unfit for surgery.

Keywords: Gallbladder, acute cholecystitis, cholecystectomy, general surgery

\section{öz}

Amaç: Akut kolesistit (AK) olgularında kolesistektominin zamanlaması halen tartışmalıdır. Bu çalışmanın amacı, AK için erken kolesistektomi (EK), geç kolesistektomi (GK) ve non-operatif tedavi (NOT) sonuçlarının karşılaştııılmasıdır.

Gereç ve Yöntem: Bir yıllık süreçte AK tanısıyla tedavi edilen hastalar EK, GK ve NOT alt gruplarına ayırıldı. Demografik veriler, laboratuvar sonuçları, görüntüleme bulguları, vücut kitle indeksi (VKI), Amerikan Anestiyoloji Derneği (ASA) skoru, cerrahi zamanlaması, ameliyat süresi, safra taşı boyutu, postoperatif komplikasyonlar ve postoperatif hastanede yatış süresini içeren parametreler analiz edildi.

Bulgular: Çalışmaya dahil olan 125 hastanın; 71'i $(\% 56,8)$ EK grubunda, 29'u (\%23,2) GK grubunda ve 25'i (\%20) NOT grubundaydı. Hastalardan NOT grubunu oluşturanlar, göreceli olarak daha yaşlı idi $(p<0,05)$. Çalışma alt grupları arasında VKi değerleri ve fizik muayene bulguları benzerdi $(p>0,05)$. Alt gruplardan NOT grubunda; ASA 3 skoru sıklığı, ortalama bilirubin değerleri ile aspartat aminotransferaz ve alanin aminotransferaz değerleri daha yüksek iken ortalama hemoglobin değeri daha düşüktü $(p<0,05)$. Boyutları $1 \mathrm{~cm}$ 'den küçük safra taşları GK grubunda daha sık olarak gözlendi $(p<0,05)$. Ortalama ameliyat süresi, açık ameliyata geçiş oranları ve postoperatif komplikasyon oranları EK ve GK grupları arasında benzer saptandı $(p>0,05)$. Hastanede yatış süresinin GK grubunda daha kısa olduğu gözlendi $(p<0,05)$.

Address for Correspondence: Tunç Eren, Istanbul Medeniyet University Göztepe City Hospital, Department of General Surgery, Istanbul, Turkey

Phone: +90 5322447494 E-mail: drtunceren@gmail.com ORCID ID: orcid.org/0000-0001-7651-4321

Cite as: Ekinci Ö, Eren T, Gapbarov A, Beyazadam D, Bulut N, Leblebici M, Alimoğlu O. Management Strategies for Acute Cholecystitis: Is the Timing of Surgery Important? Med J Bakirkoy 2021;17:312-319

Received: 27.04.2021 
Sonuç: Klinik ve laboratuvar bulguları hastanın ameliyat için uygun olmadığını göstermediği sürece, akut kolesistit olgularının cerrahi tedavisi, hastaneye yatışın ilk haftası içerisinde herhangi bir zamanda gerçekleştirilebilir.

Anahtar Kelimeler: Safra kesesi, akut kolesistit, kolesistektomi, genel cerrahi

\section{INTRODUCTION}

Laparoscopic cholecystectomy (LC) was first performed by Mühe in 1985 and was accepted as a safe and effective treatment method for symptomatic gallstone disease by the National Institutes of Health in $1992(1,2)$. Approximately, $80 \%$ of patients harboring gallstones are asymptomatic (3). When symptomatic gallstones obstruct the cystic duct, the subsequent distension of the gallbladder may be complicated with inflammation, infection, and ischemia that lead to acute cholecystitis (AC) (4). Annually, 1-2\% of patients with gallstones present with biliary colic, jaundice, and biliary pancreatitis, whereas AC develops in $10 \%$ of cases $(5,6)$.

Epigastric and/or right upper quadrant pain, as well as Murphy's sign, are the common physical examination findings of AC (3). White blood cell (WBC) count and C-reactive protein (CRP) levels are usually elevated (4). Imaging studies frequently reveal a thickened gallbladder wall and pericholecystic fluid in cases with AC (7).

According to the latest updated Tokyo guidelines in 2018, the diagnostic criteria for $A C$ are based on the local and systemic signs of inflammation in addition to the imaging findings (1). Pain, tenderness, and/or a palpable mass in the right upper quadrant and Murphy's sign are the local signs, whereas fever, elevated WBC count, and a raised CRP level are the systemic signs of inflammation. Characteristic imaging findings for $A C$ include the measurement of the gallbladder wall thickness of $\geq 5 \mathrm{~mm}$, the presence of pericholecystic fluid, and the detection of abdominal tenderness by the pressure of the probe at ultrasonographic evaluation (sonographic Murphy's sign) $(8,9)$.

There's no doubt that $L C$ is the treatment of choice for $A C$; however, the timing for the operation is still controversial (10). According to the 2018 Tokyo guidelines, early cholecystectomy $(E C)$ that is to be performed within the first week after the onset of AC symptoms is recommended (11). Thus, this study aimed to evaluate the treatment outcomes of patients with $A C$, either having undergone $(E C)$ or delayed cholecystectomy (DC), or having been managed non-operatively (NOM).

\section{METHODS}

The data of patients treated with the diagnosis of $A C$ in the Department of General Surgery between July 2018 and
July 2019 was prospectively recorded and retrospectively analyzed. This study was approved by the Institutional Review Ethics Committee of Istanbul Medeniyet University Göztepe City Hospital (IRB: 2019/0327). Signed informed consent forms were obtained from all patients. All procedures were performed following the 1964 Helsinki declaration and its later amendments or comparable ethical standards.

In all included patients, the diagnosis of $A C$ was made based on their findings following the diagnostic criteria of the 2018 Tokyo guidelines. All patients were offered surgery following the diagnostic evaluations, and were divided into three subgroups: 1) EC group included patients who underwent cholecystectomy at any time during their index admission, 2) DC group included patients who underwent cholecystectomy after 4-6 weeks following their initial medical treatment as this subgroup comprised of patients who refused the proposed early surgical intervention during their first hospitalization period, 3) NOM group included patients who did not undergo cholecystectomy following their initial medical treatment since they were unfit for surgery or refused the surgical treatment option.

Patients who presented with biliary colic, diagnosed with an acute abdomen, younger than 18 or older than 90 years old, and were initially treated with percutaneous cholecystostomy were excluded from the study. Parameters, including demographics, laboratory results, imaging findings, body mass index (BMI), American Society of Anesthesiologists (ASA) score, the timing of surgery, operative time, gallstone size, postoperative complications, and postoperative length of hospital stay, were recorded and compared among the groups.

\section{Statistical Analysis}

Statistical analyses were performed using the International Business Machines ${ }^{\circledR}$ Statistical Package for the Social Sciences $®$ version 22.0 Software (IBM Industries, New York, USA). In addition to the descriptive statistical methods (mean, standard deviation, median, minimum, maximum, and ratio), the Mann-Whitney $U$ test was used to compare numerical quantities of parameters with abnormal distribution between the two groups. Differences among more than two groups with normal distribution were analyzed with the analysis of variance, whereas the KruskalWallis test was used for maldistribution among the groups. 
Significance in multiple comparisons was evaluated via post-hoc tests, including Tukey and Bonferroni corrections, whereas Pearson's Chi-squared test was used for categorical data analysis. Differences were considered statistically significant with $p$-values of $<0.05$.

\section{RESULTS}

The study group of 125 patients with $A C$ comprised 71 (56.8\%) patients in the EC, 29 (23.2\%) in the DC, and 25 (20\%) in the NOM group. The EC group consisted of 37 (52.1\%) males and 34 (47.9\%) females with a mean age of $51.5 \pm 14.0$ (range: 20-86) years, whereas the DC group consisted of 15 (51.7\%) males and 14 (48.3\%) females with a mean age of 55.9 \pm 11.3 (range: $25-72$ ) years and the NOM group consisted of $16(64.0 \%)$ males and $9(36.0 \%)$ females with a mean age of $76.6 \pm 11.9$ (range: $45-94$ ) years. Patients in the NOM group were relatively older than the other subgroups $(p=0.001)$. No statistically significant difference was found among the subgroups concerning gender $(p=0.559)$ (Table 1).

The mean BMI value of the EC group was 28.9 \pm 4.6 (range: 19.6-47.2), whereas the DC group was $28.5 \pm 4.0$ (range: 22.6 37.9 ) and the NOM group was $26.8 \pm 4.2$ (range: 16.2-33.4), which reveal no significant difference among the subgroups $(p=0.178)$. The ASA score evaluation revealed that patients with the ASA scores of 1 and 2 were more common in the EC group, whereas the incidence of ASA score of 3 was significantly higher in the NOM group ( $p=0.039$ ) (Table 1).

Regarding the laboratory results, the mean levels of total bilirubin, aspartate aminotransferase (AST), and alanine aminotransferase (ALT) were significantly higher in the DC and NOM groups compared to the EC group ( $p=0.033$, $p=0.001$, and $p=0.036$, respectively). The mean direct bilirubin levels were significantly higher in the EC than the
NOM group and the mean lactate dehydrogenase levels were significantly higher in the DC group $(p=0.020$ and $p=0.031$, respectively). Contrarily, the mean hemoglobin value of the NOM group was significantly lower than the other subgroups ( $p=0.008$ ) (Table 2$)$.

According to the physical examination findings, sole right upper quadrant pain without the presence of Murphy's sign was found in 23 (32.4\%) patients, whereas 48 (67.6\%) patients presented with accompanying Murphy's sign in the EC group. Right upper quadrant pain was solely present in $8(27.6 \%)$ patients in the DC group and $9(36 \%)$ in the NOM group, whereas accompanying Murphy's sign was found in 21 (72.4\%) patients in the DC group and 16 (64\%) in the NOM group. No statistical differences were detected among the three subgroups according to the physical examination findings $(p=0.799)$ (Table 3 ).

The DC group had 16 (55.2\%) patients who harbored gallstones that were $<1 \mathrm{~cm}$, whereas gallstones with a size of $1 \mathrm{~cm}$ or larger were detected in $48(67.6 \%)$ patients in the EC group and 14 (56.0\%) patients in the NOM group. Gallstones smaller than $1 \mathrm{~cm}$ were significantly more common in the DC group compared to the other subgroups $(p=0.001)$ (Table 3).

The mean duration between the onset of symptoms and the time of cholecystectomy was calculated to be $130.0 \pm 86.9$ (range: 24-480) $\mathrm{h}$ in the EC group. The mean operative time was $68.3 \pm 38.4$ (range: $10-180$ ) $\mathrm{min}$ in the EC group and $72.3 \pm 36.2$ (range: $24-480$ ) $\mathrm{min}$ in the DC group, without statistically significant difference $(p=0.495)$ (Table 3$)$.

All cholecystectomies were started laparoscopically. In the EC group, LC was completed in 69 (97.2\%) patients, whereas conversion to open surgery occurred in 2 (2.8\%) patients. Contrarily, LC was completed in 26 (89.7\%) and

Table 1. The distribution of demographic parameters among patient groups

\begin{tabular}{|c|c|c|c|c|c|c|}
\hline \multicolumn{3}{|c|}{ Patient groups } & EC & DC & NOM & \multirow{2}{*}{$p$} \\
\hline \multicolumn{3}{|l|}{$n(\%)$} & $71(56.8 \%)$ & $29(23.2 \%)$ & $25(20 \%)$ & \\
\hline \multirow[b]{2}{*}{ Gender } & Male & \multirow[b]{2}{*}{ n (\%) } & $37(52.1 \%)$ & $15(51.7 \%)$ & $16(64.0 \%)$ & \multirow{2}{*}{$0.559^{a}$} \\
\hline & Female & & $34(47.9 \%)$ & $14(48.3 \%)$ & $9(36.0 \%)$ & \\
\hline \multicolumn{2}{|l|}{ Age (years) } & Mean $\pm S D$ (range) & $51.5 \pm 14.0(20-86)$ & $55.9 \pm 11.3(25-72)$ & $76.6 \pm 11.9(45-94)$ & $0.001^{b}$ \\
\hline \multicolumn{2}{|c|}{ Body mass index $\left(\mathrm{kg} / \mathrm{m}^{2}\right)$} & Mean \pm SD (range) & $28.9 \pm 4.6(19.6-47.2)$ & $28.5 \pm 4.0(22.6-37.9)$ & $26.8 \pm 4.2(16.2-33.4)$ & $0.126^{b}$ \\
\hline \multirow{3}{*}{ ASA score } & I & \multirow{3}{*}{$n(\%)$} & $16(22.5 \%)$ & $6(20.7 \%)$ & $2(8.0 \%)$ & \multirow{3}{*}{$0.039^{a}$} \\
\hline & ॥ & & $50(70.4 \%)$ & $21(72.4 \%)$ & $16(64.0 \%)$ & \\
\hline & III & & $5(7.0 \%)$ & $2(6.9 \%)$ & $7(28.0 \%)$ & \\
\hline
\end{tabular}

aPearson's chi-squared test, banalysis of variance, SD: Standard deviation, n: Number of patients, EC: Early cholecystectomy, DC: Delayed cholecystectomy, NOM: Non-operative management, ASA: American Society of Anesthesiologists 
Ekinci et al. Management Strategies for Acute Cholecystitis

Table 2. The distribution of laboratory parameters among patient groups

\begin{tabular}{|c|c|c|c|c|c|c|c|c|}
\hline Laboratory parameter & $\begin{array}{l}\text { Study } \\
\text { group }\end{array}$ & Mean & $\pm \mathrm{SD}$ & Median & Min & Max & $p$ & $\begin{array}{l}\text { Post hoc } \\
\text { (groups) }\end{array}$ \\
\hline \multirow{3}{*}{$\begin{array}{l}\text { White blood } \\
\text { cell count } \\
\left(10^{3} / \mu \mathrm{L}\right)\end{array}$} & EC & 13.0 & 3.7 & 12.9 & 5.9 & 23.2 & \multirow{3}{*}{$0.087^{a}$} & \multirow{3}{*}{$\mathrm{N} / \mathrm{A}$} \\
\hline & DC & 14.0 & 4.8 & 13.4 & 5.4 & 29.5 & & \\
\hline & NOM & 11.6 & 5.9 & 10.4 & 4.8 & 32.6 & & \\
\hline \multirow{3}{*}{$\begin{array}{l}\text { Hemoglobin } \\
\text { (g/dL) }\end{array}$} & EC & 13.7 & 1.6 & 13.7 & 10.2 & 17.1 & \multirow{3}{*}{$0.008^{a}$} & \multirow{3}{*}{$\mathrm{NOM}<\mathrm{EC}, \mathrm{DC}$} \\
\hline & $\mathrm{DC}$ & 14.1 & 1.6 & 14.5 & 10.2 & 16.5 & & \\
\hline & NOM & 12.7 & 1.8 & 1.5 & 9.6 & 16.9 & & \\
\hline \multirow{3}{*}{$\begin{array}{l}\text { Total } \\
\text { bilirubin } \\
\text { (mg/dL) }\end{array}$} & EC & 1.0 & 0.6 & 0.8 & 0.1 & 2.8 & \multirow{3}{*}{$0.033^{b}$} & \multirow{3}{*}{$\mathrm{EC}<\mathrm{DC}, \mathrm{NOM}$} \\
\hline & $\mathrm{DC}$ & 1.4 & 1.2 & 1.0 & 0.3 & 5.1 & & \\
\hline & NOM & 1.5 & 1.2 & 1.2 & 0.6 & 4.4 & & \\
\hline \multirow{3}{*}{$\begin{array}{l}\text { Direct } \\
\text { bilirubin } \\
\text { (mg/dL) }\end{array}$} & EC & 0.4 & 0.3 & 0.3 & 0.1 & 1.6 & \multirow{3}{*}{$0.020^{b}$} & \multirow{3}{*}{$\mathrm{EC}<\mathrm{NOM}$} \\
\hline & $\mathrm{DC}$ & 0.6 & 0.6 & 0.3 & 0.1 & 2.5 & & \\
\hline & NOM & 0.9 & 0.8 & 0.6 & 0.1 & 3.2 & & \\
\hline \multirow{3}{*}{$\begin{array}{l}\text { Indirect } \\
\text { bilirubin } \\
\text { (mg/dL) }\end{array}$} & EC & 0.6 & 0.4 & 0.6 & 0.0 & 2.0 & \multirow{3}{*}{$0.250^{\mathrm{b}}$} & \multirow{3}{*}{$\mathrm{N} / \mathrm{A}$} \\
\hline & $\mathrm{DC}$ & 0.8 & 0.8 & 0.7 & 0.2 & 4.3 & & \\
\hline & NOM & 0.6 & 0.4 & 0.5 & 0.1 & 1.3 & & \\
\hline \multirow{3}{*}{$\begin{array}{l}\text { C-reactive } \\
\text { protein } \\
(\mathrm{mg} / \mathrm{dL})\end{array}$} & EC & 6.3 & 7.4 & 4.0 & 0.1 & 34.0 & \multirow{3}{*}{$0.571^{b}$} & \multirow{3}{*}{ N/A } \\
\hline & $\mathrm{DC}$ & 5.5 & 9.4 & 0.9 & 0.1 & 32.3 & & \\
\hline & NOM & 6.7 & 7.9 & 3.8 & 0.1 & 31.1 & & \\
\hline \multirow{3}{*}{$\begin{array}{l}\text { Aspartate aminotransferase } \\
\text { (IU/L) }\end{array}$} & $\mathrm{EC}$ & 30.3 & 42.3 & 20.0 & 10.0 & 323.0 & \multirow{3}{*}{$0.001^{b}$} & \multirow{3}{*}{$\mathrm{EC}<\mathrm{DC}, \mathrm{NOM}$} \\
\hline & DC & 92.9 & 97.3 & 46.5 & 8.0 & 376.0 & & \\
\hline & NOM & 103.0 & 109.5 & 35.0 & 8.8 & 417.0 & & \\
\hline \multirow{3}{*}{ Alanine aminotransferase (IU/L) } & EC & 34.7 & 41.7 & 20.0 & 10.0 & 235.0 & \multirow{3}{*}{$0.036^{b}$} & \multirow{3}{*}{$\mathrm{EC}<\mathrm{DC}, \mathrm{NOM}$} \\
\hline & DC & 93.5 & 114.9 & 35.0 & 9.0 & 384.0 & & \\
\hline & NOM & 86.9 & 93.3 & 43.0 & 8.0 & 359.0 & & \\
\hline \multirow{3}{*}{$\begin{array}{l}\text { Gamma-glutamyl transferase } \\
\text { (IU/L) }\end{array}$} & EC & 65.0 & 90.7 & 35.0 & 10.0 & 562.0 & \multirow{3}{*}{$0.092^{\mathrm{b}}$} & \\
\hline & $\mathrm{DC}$ & 221.9 & 309.8 & 42.0 & 14.0 & 1093.0 & & $\mathrm{~N} / \mathrm{A}$ \\
\hline & NOM & 237.0 & 288.1 & 77.5 & 12.0 & 961.0 & & \\
\hline Alkaline & EC & 96.7 & 51.9 & 86.0 & 39.0 & 360.0 & & \\
\hline phosphatase & $\mathrm{DC}$ & 112.1 & 67.7 & 85.0 & 52.0 & 317.0 & $0.262^{\mathrm{b}}$ & $\mathrm{N} / \mathrm{A}$ \\
\hline (IU/L) & NOM & 149.5 & 122.3 & 93.5 & 62.0 & 570.0 & & \\
\hline & EC & 226.4 & 76.9 & 212.0 & 0.0 & 591.0 & & \\
\hline $\begin{array}{l}\text { Lactate } \\
\text { dehydrogenase (IU/L) }\end{array}$ & $\mathrm{DC}$ & 295.7 & 121.0 & 270.5 & 149.0 & 589.0 & $0.031^{b}$ & $E C<D C$ \\
\hline & NOM & 261.8 & 92.2 & 231.0 & 168.0 & 523.0 & & \\
\hline & EC & 53.0 & 27.1 & 47.0 & 12.0 & 138.0 & & \\
\hline $\begin{array}{l}\text { Amylase } \\
\text { (IU/L) }\end{array}$ & $\mathrm{DC}$ & 82.1 & 81.0 & 52.5 & 24.0 & 377.0 & $0.182^{b}$ & N/A \\
\hline & NOM & 96.2 & 113.0 & 65.5 & 19.0 & 544.0 & & \\
\hline
\end{tabular}

analysis of variance (post-hoc: Tukey), 'bKruskal-Wallis (post-hoc: Bonferroni), SD: Standard deviation, Min: Minimum, Max: Maximum, N/A: Not applicable EC: Early cholecystectomy, DC: Delayed cholecystectomy, NOM: Non-operative management 
conversion took place in 3 (10.3\%) patients in the DC group. The conversion rates were found to be similar between the two subgroups ( $p=0.117$ ) (Table 3 ).

In the early postoperative period, 66 (93.0\%) patients in the EC and $27(93.1 \%)$ in the DC group were observed to be free of complications as they were discharged eventless. However, the EC group had 5 (7.0\%) patients who developed postoperative complications including atelectasis, pulmonary embolism, hemorrhage, intraabdominal fluid collection, and cystic stump leakage. Contrarily, the DC group had 2 (6.9\%) patients who developed postoperative complications, which were intraabdominal fluid collection and hyperbilirubinemia. No significant difference was detected between the EC and DC groups regarding postoperative complications ( $p=0.608$ ) (Table 3 ).

The mean duration of postoperative hospital stay was calculated as 2.3 \pm 2.4 (range: $1-15$ ) days in the EC group and $1.7 \pm 2.0$ (range: $1-9$ ) days in the DC group. The length of hospital stay was shorter in the DC group $(p=0.001)$ (Table 3).

\section{DISCUSSION}

Females are more likely to develop gallstones with an approximately threefold prevalence compared to males, and $90-95 \%$ of $A C$ cases occur due to complicated gallstone disease (12). To date, controversy still exists regarding the best management method and timing of surgery for $A C$ (10).

A meta-analysis published by Gallagher et al. (13) indicated that the mean age of patients in the EC and DC groups were 55.0 and 56.5, respectively. Our study revealed that the mean ages of patients in the EC and DC groups were 51.5 and 55.9, respectively, whereas in the NOM group was 76.6 years. The mean age of patients in the NOM group was significantly higher compared with the other groups $(p<0.05)$. The elder patients who also have comorbidities would be unfit for surgery, thus the rates of NOM, which included broad-spectrum antibiotherapy and percutaneous cholecystostomy, were higher. However, a fewer number of younger patients were in the NOM group since these patients refused surgical treatment.

Table 3. The distribution of clinical parameters and surgical outcomes among patient groups

\begin{tabular}{|c|c|c|c|c|c|c|}
\hline \multicolumn{3}{|c|}{ Patient groups } & EC & DC & NOM & \multirow{2}{*}{$\mathrm{p}$} \\
\hline n (\%) & & & $71(56.8 \%)$ & $29(23.2 \%)$ & $25(20 \%)$ & \\
\hline \multirow{2}{*}{$\begin{array}{l}\text { Physical } \\
\text { examination }\end{array}$} & $\begin{array}{l}\text { Right upper quadrant } \\
\text { tenderness only }\end{array}$ & \multirow[t]{2}{*}{$n(\%)$} & $23(32.4 \%)$ & $8(27.6 \%)$ & $9(36.0 \%)$ & \multirow[t]{2}{*}{$0.799^{a}$} \\
\hline & Murphy's sign & & $48(67.6 \%)$ & $21(72.4 \%)$ & $16(64.0)$ & \\
\hline \multirow{2}{*}{$\begin{array}{l}\text { Gallstone/ } \\
\text { sludge }\end{array}$} & Sludge & \multirow{2}{*}{$\mathrm{n}(\%)$} & $2(2.8 \%)$ & $3(10.3 \%)$ & $6(24.0 \%)$ & \multirow{2}{*}{$0.001^{\circ}$} \\
\hline & Gallstone $\geq 1 \mathrm{~cm}$ & & $48(67.6 \%)$ & $10(34.5 \%)$ & $14(56.0 \%)$ & \\
\hline \multicolumn{2}{|c|}{ Time since onset of symptoms (hours) } & Mean \pm SD (range) & $130.0 \pm 86.9(24-480)$ & - & - & $\mathrm{N} / \mathrm{A}$ \\
\hline \multirow{2}{*}{$\begin{array}{l}\text { Type of } \\
\text { surgery }\end{array}$} & Laparoscopic cholecystectomy & \multirow{2}{*}{$n(\%)$} & $69(97.2 \%)$ & $26(89.7 \%)$ & - & \multirow[b]{2}{*}{$0.117^{\mathrm{a}}$} \\
\hline & Conversion to open surgery & & $2(2.8 \%)$ & $3(10.3 \%)$ & - & \\
\hline \multirow[t]{5}{*}{ Complication } & Pulmonary embolism & \multirow{5}{*}{$\mathrm{n}(\%)$} & $1(1.4 \%)$ & - & - & \multirow{5}{*}{$0.608^{a}$} \\
\hline & Hemorrhage/laparotomy & & $1(1.4 \%)$ & - & - & \\
\hline & Intraabdominal fluid collection & & $1(1.4 \%)$ & $1(3.5 \%)$ & - & \\
\hline & Cystic stump leakage & & $1(1.4 \%)$ & - & - & \\
\hline & Hyperbilirubinemia & & - & $1(3.5 \%)$ & - & \\
\hline \multicolumn{2}{|c|}{ Postoperative hospital stay (days) } & Mean \pm SD (range) & $2.3 \pm 2.3(1-15)$ & $1.7 \pm 1.9(1-9)$ & - & $0.001^{c}$ \\
\hline
\end{tabular}

aPearson's chi-squared test, banalysis of variance, cMann-Whitney U test, n: Number of patients, SD: Standard deviation, N/A: Not applicable, EC: Early cholecystectomy, DC: Delayed cholecystectomy, NOM: Non-operative management 
The current 2018 Tokyo Guidelines suggest that diagnostic criteria for AC include Murphy's sign and right upper quadrant pain (1). Murphy's sign was the most common physical examination finding in our EC and DC groups; however, no significant difference was detected among the subgroups regarding physical examination findings ( $p>0.05$ ).

Cystic duct obstruction by gallstones is the main reason for the development of AC (4). Our study demonstrates that subsentimetric gallstones were significantly higher in the DC group, whereas gallstones of $>1 \mathrm{~cm}$ were mostly detected in the EC and NOM groups $(p<0.05)$. Subsentimetric gallstones that cause $\mathrm{AC}$ have a higher probability to cause abnormalities in laboratory findings; hence, leading to timeconsuming additional investigations to evaluate the biliary tract, which is considered the main reason for preferring management with medical treatment and DC following $>4-6$ weeks in cases of gallstones of $<1 \mathrm{~cm}$. However, the relation between early or late cholecystectomies and gallstone size is yet controversial.

Patients who present with AC might also have accompanying laboratory findings, such as high levels of bilirubin and transaminases (12). The extrahepatic biliary tract must be evaluated with magnetic resonance cholangiopancreatography in the absence of spontaneous recovery in the laboratory findings because of the increased risks of postoperative complications, such as jaundice and cystic stump leakage. Then, cholangiographic evaluation and gallstone extraction should be performed via endoscopic retrograde cholangiopancreatography (ERCP) if indicated (14). Our findings reveal that laboratory parameters, including total bilirubin, direct bilirubin, AST, and ALT, were observed to be lower in the EC group compared to the other two groups $(p<0.05)$. We agree that should the bilirubin and liver enzymes are elevated, EC ought to be avoided and LC should be delayed until the values reach normal limits.

One of the risk factors that are associated with prolonged surgery and conversion to open surgery is high BMI $(1,15)$. Our study revealed that the mean BMI value was $28.06 \mathrm{~kg} /$ $\mathrm{m}^{2}$, without statistically significant difference compared among the study subgroups ( $p>0.05$ ).

Opinions are presented that elderly patients with ASA scores of $\geq 2$ will have cardiopulmonary side effects of pneumoperitoneum; however, the postoperative results of LC in the elderly patients have been satisfactory (16). Our study found that patients with an ASA score of 3 were significantly higher in the NOM group than in the other subgroups $(p<0.05)$.
Studies that question the paradigm regarding the concept of "the first 72-96 hours" requirement for EC that even took place in reference textbooks report that this period can be extended up to $168 \mathrm{~h}(11,12)$. Our study revealed that patients in the EC group were operated on an average of 5.4 days $(130.0 \pm 86.9 \mathrm{~h})$ following the onset of symptoms. Contrary to other studies, our patients underwent cholecystectomy within the first week after their hospitalization, regardless of the duration from the onset of complaints, which is considered a bold surgical approach. However, the comparative statistical analysis between the EC group in which the patients were operated on in the first week regardless of the onset of their symptoms and the DC group in which the operations were performed after 4-6 weeks demonstrated no significant difference in terms of complication rates between the two subgroups $(p<0.05)$.

Additionally, the mean operative time was calculated as $70.0 \pm 39.9 \mathrm{~min}$ in the EC group and $72.3 \pm 36.2 \mathrm{~min}$ in the DC group, without statistically significant difference $(p<0.05)$.

Gurusamy et al. (17) compared the groups of EC and DC and reported similar rates of biliary tract injury and conversion. Our study revealed no biliary tract injuries in patients who underwent cholecystectomy, and no statistically significant difference was found between the EC and DC groups regarding the conversion rates $(p>0.05)$.

One of the most common complications following cholecystectomy includes bile duct leakage due to the presence of a Luschka duct. Peritonitis, bleeding, surgical site infection, and intraabdominal collection are other complications that might develop after cholecystectomy $(18,19)$. Our study revealed 1 (1.4\%) patient who received urgent laparotomy because of hemorrhage following EC, in which hemostasis was successfully achieved. One patient $(1.4 \%)$ in the EC group and one patient (3.4\%) in the DC group developed intraabdominal fluid collections, who were treated by percutaneous drainage catheter application. One patient (1.4\%) who underwent EC developed cystic stump leakage due to choledocholithiasis, which was then managed by stone extraction and plastic stent placement via ERCP. Apart from the aforementioned surgical complications, other postoperative complications included atelectasis in 1 (1.4\%) patient and pulmonary embolism in another 1 (1.4\%) patient in the EC group, whereas 1 (3.5\%) patient in the DC group developed postoperative hyperbilirubinemia, all of whom were medically managed without any interventions. No statistically significant difference was found between the subgroups regarding overall complications ( $p>0.05$ ).

A meta-analysis that was conducted by Wu et al. (20) reported that patients in the EC group had a shorter length 
of hospital stay, yet longer operative times. Our study revealed that the mean length of hospital stay of the EC group was statistically longer than the DC group $(p<0.05)$. Apart from the surgical complications, a longer hospital stay was attributed to the prolonged waiting period for the improvement of patients' clinical conditions and laboratory findings due to the systemic inflammatory reaction of $A C$ before their perioperative periods.

\section{Study Limitations}

A limitation of our study included the relatively low number of patients and its single-center, cross-sectional study design. Contrarily, operating the patients in the EC group within the first week of their index hospitalization, regardless of the day from the onset of symptoms, can be attributed as the unique feature of our study.

Of the two main issues that were addressed in the 2016 guidelines of The World Society of Emergency Surgery, the first one is that surgery is clinically superior to follow-up, and the second is that cholecystectomy is considered the gold standard treatment of AC (21). Our findings recommend performing $E C$ regardless of the onset of symptoms in the absence of confounding factors, such as poor clinical status, altered laboratory findings, advanced age, or comorbidities, which preclude surgical treatment for patients who are hospitalized with AC.

\section{CONCLUSION}

The surgical treatment of hospitalized patients with $A C$ can safely be performed anytime within the first week of their admissions regardless of the time from the onset of symptoms unless the clinical and laboratory findings render the patient unfit for surgery. Therefore, achieving a definitive treatment at once is possible, without the need for further hospitalization. The findings of our study might suggest a paradigm shift regarding the "first 72-96 hours" requirement for cholecystectomy in $\mathrm{AC}$ cases.

\section{ETHICS}

Ethics Committee Approval: This study was approved by the Institutional Review Ethics Committee of Istanbul Medeniyet University Göztepe City Hospital (IRB: 2019/0327).

Informed Consent: Signed informed consent forms were obtained from all patients.

\section{Authorship Contributions}

Surgical and Medical Practices: Ö.E., T.E., A.G., D.B., M.L., O.A., Concept: Ö.E., T.E., A.G., N.B., O.A., Design: Ö.E., T.E., O.A., Data Collection or Processing: Ö.E., T.E., A.G.,
N.B., M.L., O.A., Analysis or Interpretation: Ö.E., T.E., A.G., D.B., N.B., M.L., O.A., Literature Search: Ö.E., T.E., A.G., D.B., M.L., Writing: Ö.E., T.E., A.G., D.B., N.B.

Conflict of Interest: No conflict of interest was declared by the authors.

Financial Disclosure: The authors declared that this study received no financial support.

\section{REFERENCES}

1. Wakabayashi G, Iwashita Y, Hibi T, Takada T, Strasberg SM, Asbun HJ, et al. Tokyo Guidelines 2018: surgical management of acute cholecystitis: safe steps in laparoscopic cholecystectomy for acute cholecystitis (with videos). J Hepatobiliary Pancreat Sci 2018;25:73-86.

2. Gollan JL, Bulkley GB, Diehl AM, Elashoff JD, Federle MP, Hogan WJ, et al. Gallstones and laparoscopic cholecystectomy. JAMA 1993;269:1018-24.

3. Friedman GD. Natural history of asymptomatic and symptomatic gallstones. Am J Surg 1993;165:399-404.

4. Mou D, Tesfasilassie T, Hirji S, Ashley SW. Advances in the management of acute cholecystitis. Ann Gastroenterol Surg 2019;3:247-53.

5. Friedman GD, Raviola CA, Fireman B. Prognosis of gallstones with mild or no symptoms: 25 years of follow-up in a health maintenance organization. J Clin Epidemiol 1989;42:127-36.

6. Ko CW, Lee SP. Gastrointestinal disorders of the critically ill. Biliary sludge and cholecystitis. Best Pract Res Clin Gastroenterol 2003; 17:383-96.

7. Kaoutzanis C, Davies E, Leichtle SW, Welch KB, Winter S, Lampman $\mathrm{RM}$, et al. Abdominal ultrasound versus hepato-imino diacetic acid scan in diagnosing acute cholecystitis--what is the real benefit? J Surg Res 2014;188:44-52.

8. Yokoe M, Takada T, Strasberg SM, Solomkin JS, Mayumi T, Gomi $H$, et al. TG13 diagnostic criteria and severity grading of acute cholecystitis (with videos). J Hepatobiliary Pancreat Sci 2013;20:3546.

9. Yokoe M, Hata J, Takada T, Strasberg SM, Asbun HJ, Wakabayashi G, et al. Tokyo Guidelines 2018: diagnostic criteria and severity grading of acute cholecystitis (with videos). J Hepatobiliary Pancreat Sci 2018;25:41-54

10. Gurusamy KS, Davidson C, Gluud C, Davidson BR. Early versus delayed laparoscopic cholecystectomy for people with acute cholecystitis. Cochrane Database Syst Rev 2013;6:CD005440. doi: 10.1002/14651858.CD005440.pub3

11. Okamoto K, Suzuki K, Takada T, Strasberg SM, Asbun HJ, Endo I, et al. Tokyo Guidelines 2018: flow chart for the management of acute cholecystitis. J Hepatobiliary Pancreat Sci 2018;25:55-72.

12. Haisley KR, Hunter JG. Gallbladder and the extrahepatic biliary system. In: Brunicardi FC, Andersen DK, Billiar TR, Dunn DL, Hunter JG, Kao LS, et al, editors. Schwartz's Principles of Surgery, 11th ed. New York: McGraw Hill; 2019. p. 1393-427.

13. Gallagher TK, Kelly ME, Hoti E. Meta-analysis of the costeffectiveness of early versus delayed cholecystectomy for acute cholecystitis. BJS Open 2019;3:146-52.

14. Gomes CA, Junior CS, Di Saverio S, Sartelli M, Kelly MD, Gomes CC, et al. Acute calculous cholecystitis: Review of current best practices. World J Gastrointest Surg 2017;9:118-26.

15. Jensen KK, Roth NO, Krarup PM, BardramL. Surgical management of acute cholecystitis in a nationwide Danish cohort. Langenbecks Arch Surg 2019;404:589-97. 
16. Yi NJ, Han HS, Min SK. The safety of a laparoscopic cholecystectomy in acute cholecystitis in high-risk patients older than sixty with stratification based on ASA score. Minim Invasive Ther Allied Technol 2006;15:159-64.

17. Gurusamy K, Samraj K, Gluud C, Wilson E, Davidson BR. Metaanalysis of randomized controlled trials on the safety and effectiveness of early versus delayed laparoscopic cholecystectomy for acute cholecystitis. Br J Surg 2010;97:141-50.

18. Livingston $\mathrm{EH}$, Rege RV. A nationwide study of conversion from laparoscopic to open cholecystectomy. Am J Surg 2004;188:20511.

19. Lawrentschuk N, Hewitt PM, Pritchard MG. Elective laparoscopic cholecystectomy: implications of prolonged waiting times for surgery. ANZ J Surg 2003;73:890-3.
20. Wu XD, Tian X, Liu MM, Wu L, Zhao S, Zhao L. Meta-analysis comparing early versus delayed laparoscopic cholecystectomy for acute cholecystitis. Br J Surg 2015;102:1302-13.

21. Ansaloni L, Pisano $M$, Coccolini F, Peitzmann AB, Fingerhut A, Catena F, et al. 2016 WSES guidelines on acute calculous cholecystitis. World J Emerg Surg 2016;11:25. 